REPORTS OF MORPHOLOGY
Official Journal of the Scientific Society of Anatomists,
Histologists, Embryologists and Topographic Anatomists
of Ukraine
journal homepage: https://morphology-journal.com

\title{
Morphometric evaluation of features of remodelling of the venous bad of the limbs at experimental trophic ulcer and its correction
}

Sukhodolia A.I. ${ }^{1}$, Hnatjuk M.S. ${ }^{2}$, Krenyov K. Yu. ${ }^{1}$, Kolomiiets O.V. ${ }^{1}$

${ }^{1}$ National Pirogov Memorial Medical University, Vinnytsia, Ukraine

21. Gorbachevsky Ternopil National Medical University, Ternopil, Ukraine

\section{ARTICLE INFO}

Received: 29 July, 2020

Accepted: 28 August, 2020

UDC: $616.5-002.44-02: 616.14-007.64-$ 092:612.017.1]-08

\section{CORRESPONDING AUTHOR}

e-mail: vascularkolomiiets@gmail.com Kolomiiets O.V.
The progressive course of diseases of the veins of the lower extremities leads to the development of complications in more than $80 \%$ of patients with post-thrombotic disease. Purpose of the work: to study the morphometric features of remodeling of the venous bed of the extremities in experimental trophic ulcer and its correction. A complex of morphological methods was used to examine the veins of the lover limbs of 18 adult male Vietnamese pigs, which were divided into 3 groups. 1 group consisted of 6 intact practically healthy animals, the 2 group - 6 pigs with simulated trophic ulcer, the 3 group - 6 animals with Lidocaine-corrected ulcer. The area of the trophic ulcer was measured. The trophic ulcer was taken together with the surrounding tissues, from which histological micropreparations were made, which determined the diameters of capillary venules, venules, outer and inner diameters of venous vessels, the height of endothelial cells, the diameter of their nuclei, nuclear-cytoplasmic ratios in these cells, volume of damaged endotheliocytes. A correlation analysis was performed between the ulcer area and morphometric parameters. Quantitative values were processed statistically. Strong positive correlations have been established between nuclearcytoplasmic relation in endothelial cells, the relative volume of damaged endotheliocytes, and the area of the ulcer defect $(r=+0,84 \pm 0,03)$, at correction of an ulcer by Lidocaine they weakened a little. It was found that the correction of trophic ulcers with Lidocaine led to a decrease in its area by $25.8 \%$. It is established that the experimental trophic ulcer leads to pronounced remodeling of the venous bed of the lower extremities, which is characterized by significant dilation of venous vessels, venous plethora complicated by hypoxia, atrophic, dystrophic, necrobiotic, infiltrative processes and sclerosis. The use of Lidocaine in experimental trophic ulcer improves the adaptive-compensatory and regenerative processes of the modeled pathology, reduces the relative volume of damaged endothelial cells in the venous vessels of the lower extremity by $18.8 \%$ $(p<0.001)$.

Key words: trophic ulcer, veins, morphometry, Lidocaine.

\section{Introduction}

Chronic venous insufficiency is a symptom complex that characterizes a condition caused by venous disease, in particular, varicose veins, postthrombotic disease or venous angiodysplasia, caused by the presence of venous hypertension, the clinical signs of which are heaviness, fatigue of the lower extremities, edema, edema, flatulence. pain, telangiectasia, varicose veins, trophic disorders and ulcers [24].

Trophic ulcers of the lower extremities are found in almost every fifth patient with $\mathrm{CVI}$, they often recur and cause a deterioration in quality of life [7]. Trophic ulcers among the world's population are found in $0.2 \%$ of patients with varicose veins under the age of 50 years and in $2.6 \%$ - over 50 years.

Valve failure of the venous system of the lower extremities leads to the formation of persistent phlebohypertension, which progresses rapidly, causing pathogenetic and destructive changes in the soft tissues of the lower extremities.

Despite significant advances in diagnosis and treatment in recent years, the choice of pathogenetic treatment in patients with severe chronic venous insufficiency remains controversial and unresolved. The development of irreversible trophic changes in the soft tissues of the lower extremities in most patients leads to no effect from treatment 
by known methods, and even with a positive result of treatment there is a high risk of recurrence $-30-80 \%$.

The progressive course of diseases of the veins of the lower extremities leads to the development of complications in $15-25 \%$ patients with varicose veins and more than $80 \%$ of patients with postthrombotic disease [4, 13, 30]. The complexity and versatility of pathogenetic mechanisms of trophic ulcers of the lower extremities requires different and multifaceted approaches to their treatment. At the same time, clinicians use various methods of treatment, which take into account the stage of chronic venous insufficiency, the presence of complications and the predominant syndrome [31]. It should be noted that to this day the search for timely, complete, adequate diagnosis, correction and prevention of trophic ulcers of the lower extremities [4, 13, 25, 26]. In recent decades, morphologists have widely used morphometric research methods that allow to quantify various physiological and pathological processes and adequately interpret them $[1,9,18]$.

The aim of the study was morphometric study of the features of remodeling of the venous bed of the extremities in experimental trophic ulcer and its correction.

\section{Materials and methods}

A set of morphological methods was used to examine the veins of the hind limbs of 18 adult male Vietnamese pigs, which were divided into 3 groups. The first group consisted of 6 intact practically healthy animals, the 2nd group - 6 pigs with simulated trophic ulcer [6], the 3rd group - 6 animals with trophic ulcer corrected by lidocaine at a dose of $1.0 \mathrm{mg} / \mathrm{kg}$.

Euthanasia of experimental animals was performed by bloodletting under conditions of thiopental-sodium anesthesia $[10,11]$. The trophic ulcer was removed together with the surrounding tissues, which were fixed in $10 \%$ neutral formalin solution, passed through ethyl alcohols of increasing concentration and placed in paraffin. Microtome sections 5-7 $\mu \mathrm{m}$ thick after dewaxing were stained with hematoxylin-eosin, according to Van Gieson, Mallory, toluidine blue [8]. Venous vascular morphometry was performed on histological micropreparations. The diameters of capillary venules (DCV), venules (DV), external (EDVV) and internal (IDVV) diameters of venous vessels, height of endotheliocytes (HE), diameter of their nuclei (DN), nuclearcytoplasmic relations (NCR) were determined, the relative volume of damaged endotheliocytes (RVDE) [1, 27]. 50 measurements were performed on each micropreparation. The area of the trophic ulcer was determined by the planimetric method [26]. Correlation analysis was performed between the area of the ulcer defect and the studied morphometric parameters to determine the correlation coefficient ( $r$ ). The strength of correlations was assessed by four degrees: strong $(r=0.7-0.9)$, significant $(r=0.5-0.7)$, moderate $(r=0.3-0.5)$, weak $(r<0.3)[1]$.

Quantitative morphological parameters were processed statistically. Processing of the latter was performed in the department of system statistical researches of Ivan Horbachevsky Ternopil National Medical University in the software package STATISTIKA. The difference between comparative morphometric parameters is determined by the Student's and Mann-Whitney test [12, 15]. Experiments and euthanasia of experimental animals were performed in accordance with the "General Ethical Principles of Animal Experiments" adopted by the First National Congress on Bioethics (Kyiv, 2001), in accordance with the "European Convention for the Protection of Vertebrate Animals for Research and Other Scientific Purposes", also according to the Law of Ukraine "On protection of animals from cruel treatment" (from 21.02.2006) [23].

\section{Results}

Studies have shown that the area of the ulcer defect in uncorrected trophic ulcer was equal to $(22.1 \pm 0.3) \mathrm{mm}^{2}$, and in the 3rd group of observations (corrected ulcer) $(16.4 \pm 9.2) \mathrm{mm}^{2}$. These morphometric parameters were statistically significant $(p<0.001)$ differed from each other and the last quantitative morphological index was lower than the previous one by $25.8 \%$. Therefore, the correction of trophic ulcers with lidocaine led to a marked reduction in the area of the ulcer defect. The obtained morphometric parameters of the venous bed of the lower extremities are presented in table 1.

A comprehensive analysis of the data in Table 1 showed that the studied morphometric parameters of groups 2 and 3 of the observation groups differed from similar controls. Thus, the diameter of the venules in the simulated trophic ulcer was statistically significantly $(p<0.001)$ increased from $(12.85 \pm 0.09) \mu \mathrm{m}$ to $(15.90 \pm 0.12) \mu \mathrm{m}$, ie by $23.7 \%$. With corrective correction of the simulated pathology, this quantitative morphological index decreased by $15.1 \%$ compared with the above, but did not reach the level of control $(13.50 \pm 0.09) \mu \mathrm{m}(p<0.01)$. The diameter of venules in group 2 of experimental animals with a pronounced statistically significant difference $(p<0.001)$ increased by $21.9 \%$, and in group 3 was reduced by $14.9 \%(p<0.001)$ compared to the same previous parameter.

Table 1. Morphometric characteristics of the venous bed of the lower extremities of experimental animals $(\mathrm{M} \pm \mathrm{m})$.

\begin{tabular}{|c|c|c|c|}
\hline \multirow{2}{*}{ Indicator } & \multicolumn{3}{|c|}{ Observation group } \\
\hline & 1 group & 2 group & 3 group \\
\hline $\mathrm{DCV}, \mu \mathrm{m}$ & $12,85 \pm 0,09$ & $15,90 \pm 0,12^{\star \star \star}$ & $13,50 \pm 0,09^{* *}$ \\
\hline $\mathrm{DV}, \mu \mathrm{m}$ & $26,97 \pm 0,15$ & $32,80 \pm 0,18^{* * *}$ & $27,90 \pm 0,15^{* *}$ \\
\hline EDVV, $\mu \mathrm{m}$ & $40,34 \pm 0,33$ & $47,76 \pm 0,27^{\star \star \star}$ & $41,80 \pm 0,24^{\star *}$ \\
\hline IDVV, $\mu \mathrm{m}$ & $28,33 \pm 0,21$ & $34,62 \pm 0,24^{\star \star \star}$ & $30,10 \pm 0,21^{* * *}$ \\
\hline $\mathrm{HE}, \mu \mathrm{m}$ & $4,821 \pm 0,031$ & $4,501 \pm 0,031^{* \star *}$ & $4,661 \pm 0,031^{\text {** }}$ \\
\hline $\mathrm{DN}, \mu \mathrm{m}$ & $3,482 \pm 0,021$ & $3,432 \pm 0,021$ & $3,442 \pm 0,031$ \\
\hline NCR & $0,520 \pm 0,003$ & $0,580 \pm 0,003^{* \star *}$ & $0,545 \pm 0,005^{\star *}$ \\
\hline RVDE,\% & $2,301 \pm 0,031$ & $39,20 \pm 0,48^{\star \star *}$ & $20,40 \pm 0,16^{\star \star \star}$ \\
\hline
\end{tabular}

Notes: ${ }^{* *}-p<0,01 ;{ }^{* *}-p<0,001$ compared to the first group. 
The outer diameter of the venous vessels of the intact lower extremity was equal to $(40.34 \pm 0.33) \mu \mathrm{m}$, and in the conditions of trophic ulcer - $(47.76 \pm 0.27) \mu \mathrm{m}$. A statistically significant difference $(p<0.001)$ was found between the given morphometric parameters and the last quantitative morphological indicator exceeded the previous one by $18.4 \%$. Correction of trophic ulcers led to a decrease in the outer diameter of the veins of the lower extremity, which reached $(41.80 \pm 0.24) \mu \mathrm{m}$. The above morphometric parameter was less than the same indicator in the conditions of uncorrected trophic ulcer by $12.5 \%(p<0.01)$, and also exceeded the similar control value by $3.6 \%$ $(p<0.01)$

The inner diameter of the studied vessels in the simulated experiment was also markedly $(p<0.001)$ increased from $(28.33 \pm 0.21) \mu \mathrm{m}$ to $(34.62 \pm 0.24) \mu \mathrm{m}$, ie by $22.2 \%$. In the $3 \mathrm{rd}$ group of observations (corrected trophic ulcer) the studied morphometric parameter was statistically significant $(p<0.001)$ decreased by $17.8 \%$. At the same time, this quantitative morphological indicator differed from the similar control by $6.2 \%(p<0.001)$.

The simulated pathology (trophic ulcer) led to the structural rearrangement of endothelial cells of the veins of the lower extremities, which was confirmed by changes in their morphometric parameters [19]. Thus, in control observations, the height of endothelial cells was equal to

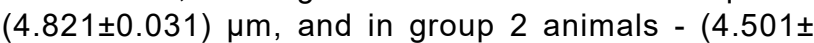
$0.031) \mu \mathrm{m}$. Between the given quantitative morphological indicators the expressed statistically significant $(p<0.001)$ difference is revealed and the last indicator appeared less than the previous by $6.6 \%$. The nuclei of these cells under the conditions of this experiment decreased by only $1.4 \%$ $(p>0.05)$. Uneven disproportionate changes in the spatial characteristics of the nucleus and cytoplasm led to violations of the relationship between them, which was determined by the nuclear-cytoplasmic relationship in the studied cells. In undamaged venous vessels of the lower extremities, this morphometric parameter was equal to $0.520 \pm 0.003$, in the 2nd group of observations $-0.580 \pm 0.003$. These quantitative morphological parameters were statistically significant $(p<0.001)$ differed. The last morphometric parameter exceeded the previous one by $11.5 \%$.

The height of endothelial cells in the conditions of corrected trophic ulcer was equal to $(4.661 \pm 0.031) \mu \mathrm{m}$. This morphometric parameter differed by $2.9 \%(p<0.01)$ from the same control, ie to a lesser extent compared with uncorrected trophic ulcer. The sizes of nuclei in the studied group of animals were similarly changed.

The correlation analysis revealed the presence of strong positive correlations in the 2 nd group of observations between nuclear-cytoplasmic relations in endotheliocytes, the relative volume of damaged endotheliocytes and the area of the ulcer defect $(r=+0.84 \pm 0.03)$. Slightly lower positive correlations were found between these quantitative morphological parameters in group 3 animals, where the correlation coefficient ranged from 0.53 to 0.65 (significant correlations).

\section{Discussion}

Nuclear-cytoplasmic ratios in endothelial cells in the conditions of corrected trophic ulcer change to a lesser extent $(4.8 \%, p<0.01)$ compared with group $3[18,28]$. It should be noted that some researchers believe that changes in nuclearcytoplasmic relationships in cells are a violation of structuralcellular homeostasis and a sign of damage to the studied structures [1,27]. It is known that the violation of a significant number of endothelial cells can lead to endothelial dysfunction, which exacerbates and worsens the course of the main pathology $[16,17]$.

Given the established positive correlation strong relationships in the second group of observations between the nuclear-cytoplasmic ratio in endothelial cells, damaged endothelial relative volume and area of the ulcer and positive correlation between quantitative morphological parameters of the third group of experimental animals, we can say that the size of ulcer defects on the limb depend on the severity of the structural adjustment of the venous bed. Remodeling of the latter significantly disrupts the drainage of venous blood, promotes the development of venous plethora and hypoxia [2, 27].

In the light microscopy examination of micropreparations of tissues of the lower extremity in a simulated trophic ulcer, a pronounced dilation and plethora of venous vessels was observed. Venous vessels of the hemomicrocirculatory tract (capillary venules and venules) are dilated, tortuous, with uneven lumen, varicose and with numerous sacculations [22]. Stasis, sludges and thrombosis foci, plasmorrhagia of the walls and paravasal space were observed in these microvessels. There were foci of diapedetic hemorrhage. In the tissues of the lower extremity were also found foci with a decrease in microvessels due to their reduction and avascular zones [14, 21]. Endothelial cells of venous vessels were edematous, dystrophically and necrobiotically altered, acquired a rounded shape with foci of their desquamation. There were also pronounced structural changes (dystrophy, necrobiosis, infiltration, sclerosis) in the cells and tissues of the lower extremity. In the corrected ulcer, the described morphological changes were similar, but less pronounced [29].

Less pronounced destructive processes and improved regeneration in the tissues of the lower extremity in experimental trophic ulcers corrected by lidocaine can be explained by the fact that the introduction of this drug limits the release of inflammatory mediators by neutrophils and monocytes, reduces the release of interleukins IL-1, IL-8, tumor necrosis factor, prostaglandins, thromboxanes, leukotrienes, lysosomal enzymes, free radicals, degranulation of mast cells with the release of histamine $[3,5,20]$.

Further, a comprehensive study of structural changes in the venous bed of the lower extremities in trophic ulcers will take into account its morphological changes by 
clinicians in the diagnosis, correction and prevention of this pathology.

\section{Conclusions}

Experimental trophic ulcer leads to a pronounced remodeling of the venous bed of the lower extremities, which

\section{References}

[1] Avtandilov, G. G. (2002). Fundamentals of Quantitative Pathological Anatomy. M.: Medicine.

[2] Baibakov, V. M. (2016). Model of morphofunctional changes of testicular drainage systems in the experiment. Pediatric surgery, 1-2, 43-45.

[3] Beaussier, M., Delbos, A., Maurice-Szamburski, A., Ecoffey, C., \& Mercadal, L. (2018). Perioperative Use of Intravenous Lidocaine. Drugs, 78(12), 1229-1246. doi: 10.1007/s40265018-0955-x

[4] Bilyaeva, O. O., Korzhik, N. P., \& Mironov, O. N. (2014). The role of enterosorbents in the treatment of complicated varicose veins. Clinical Surgery, 6, 53-55.

[5] Cuomo, R., D'Aniello, C., Grimaldi, L., Nisi, G., Botteri, G., Zerini, I., \& Brandi, C. (2015). EMLA and Lidocaine Spray: A Comparison forSurgical Debridement in Venous Leg Ulcers. Adv. Wound Care (New Rochelle), 1, 4(6), 358-361. doi: 10.1089/wound.2014.0605

[6] Falko, O. V., Shevchenko, N. A., Prokopyuk, V. Yu., Roenko, A. A., \& Prokopyuk, O. S. (2017). Comparative analysis of techniques for modeling trophic ulcers in mice. Surgery News, 25(6), 561-566.

[7] Finlayson, K. J., Parker, C. N., Miller, C., Gibb, M., Kapp, S., Ogrin, R. ... Edwards, H. E. (2018). Predicting the likelihood of venous leg ulcer recurrence: The diagnostic accuracy of a newly developed risk assessment tool. Int. Wound J., 15(5), 686-694. doi: 10.1111/iwj.12911

[8] Goralsky, L. P., Khomich, V. T., \& Konopsky, O. I. (2011). Fundamentals of histological technique and morphofunctional research methods in normal and in pathology. Zhytomyr: Polissya.

[9] Hnatyuk, M. S., \& Weak, O. B. (2016). Morphometric assessment of pulmonary heart chamber remodeling features with different types of blood supply. Achievements of Clinical and Experimental Medicine, 1, 17-20.

[10] Imbernon-Moya, A., JavierOrtiz-de Frutos, F., Sanjuan-Alvarez, M., Portero-Sanchez, I., Merinero-Palomares, R., \&Alcazar, V. (2017). Healing of chronic venous ulcer with topical sevoflurane. Int. Wound J., 14(6), 1323-1326. doi: 10.1111/ iwj.12806

[11] Imbernon-Moya, A., JavierOrtiz-de Frutos, F., Sanjuan-Alvarez, M., Portero-Sanchez, I., Merinero-Palomares, R., \& Alcazar, V. (2018). Pain and analgesic drugs in chronic venous ulcers with topical sevoflurane use. J. Vasc. Surg., 68(3), 830-835. doi: 10.1016/j.jvs.2017.11.071

[12] Ivchenko, G., I., \& Medvedev, Yu. I. (2010). Introduction to Mathematical Statistics. Moscow: LKI Publishing House.

[13] Katorkin, S. E., Melnikov, M. A., Kravtsov, P. F., Zhukov, A. A., Kushnarchuk, M. Yu., \& Repin, A. A. (2016). The effectiveness of the use of layer-by-layer dermatolipectomy in the complex treatment of patients with venous trophic ulcers of the lower extremities. Surgery News, 24(3), 255-264.

[14] Kaufman, H., Gurevich, M., Tamir, E., Keren, E., Lipkin, A., \& Hayes, P. (2018). Topical oxygen therapy stimulates healing in difficult, chronic wounds: a tertiary centre experience. $\mathrm{J}$. is characterized by pronounced dilation of venous vessels, venous plethora complicated by hypoxia, atrophic, dystrophic, necrobiotic, infiltrative and sclerotic processes.

The use of lidocaine in experimental trophic ulcers improves the adaptive-compensatory and regenerative processes and the course of the simulated pathology.

Wound Care, 27(7), 2, 426-433. doi: 10.12968/ jowc.2018.27.7.426.

[15] Lapach, S. N., Gubenko, A. V., \& Babich, P. N. (2001). Statistical methods in biomedical research. Excell. Kiev: Morion.

[16] Makarov, M. A., Avdeev, S. N., \& Chuchalin, A. G. (2012). The role of endothelial dysfunction and arterial stiffness in the pathogenesis of chronic obstructive pulmonary disease. Therapeutic Archive, 3, 74-77.

[17] Naluzhna, T. V. (2013). Endothelial and diastolic heart dysfunction in patients with coronary heart disease in combination with mitral valve prolapse syndrome. Clinical and Experimental Pathology, 12(3), 119-122.

[18] Norman, G., Westby, M. J., Stubbs, N., Dumville, J. C. \& Cullum, N. (2016). A 'test and treat' strategy forelevated wound protease activity forhealing in venous leg ulcers. Cochrane Database Syst. Rev., 15(1), CD011753. doi: 10.1002/14651858

[19] O'Meara, S., Al-Kurdi, D., Ologun, Y., Ovington, L. G., MartynSt James, M., \& Richardson, R. (2014). Antibiotics and antiseptics for venous leg ulcers. Cochrane Database Syst. Rev., 10(1), CD003557. doi: 10.1002/ 14651858.CD003557.pub5

[20] Ovechkin, A. M., \& Becker, A. A. (2017). Intravenous infusion of Lidocaine as a promising component of multimodal analgesia affecting the early postoperative period. Regional Anesthesia and Acute Pain Management, 11(2), 73-83.

[21] Petri, M., Stoffels, I., Jose, J., Leyh, J., Schulz, A., Dissemond, J. ... Klode, J. (2016). Photoacoustic imaging of real-time oxygen changes in chronic leg ulcers aftertopical application of a haemoglobin spray: a pilot study. Wound Care, 25(2), 87, 8991. doi: 10.12968/jowc.2016.25.2.87

[22] Raffetto, J. D., Eberhardt, R. T., Dean, S. M., Ligi, D., \& Mannello, F. (2016). Pharmacologic treatment to improve venous leg ulcerhealing. Vasc. Surg. Venous Lymphat. Disord., 4(3), 371374. doi: 10.1016/j.jvsv.2015.10.002

[23] Reznikov, O. G. (2003). General ethical principles of animal experiments. Endocrinology, 8, 142-145.

[24] Saveliev, B., Gologorodsky, V., \& Kirienko, A. (2001). Phlebology. A guide for physicians ed.: by V.S.Savelyev. M.: Medicine.

[25] Sopata, M., Kucharzewski, M., \& Tomaszewska, E. (2016). Antiseptic with modern wound dressings in the treatment of venous leg ulcers: clinical and microbiological aspects. $J$. Wound Care, 25(8), 419-426. doi: 10.12968/ jowc.2016.25.8.419

[26] Shutov, Yu. M., Shutova, M. Z., \& Kotrekhova, A. S. (2015). Complex local treatment of purulent-necrotic complications of diabetic foot syndrome in a polyclinic. Clinical Medicine, 3 , 32-39.

[27] Tatarchuk, L. V. (2018). Morphofunctional reconstruction of the venous bed of the ileum in postresection portal hypertension. Hospital Surgery, 4, 121-125.

[28] Thistlethwaite, K. R., Finlayson, K. J., Cooper, P. D., Brown, B., Bennett, M. H., Kay, G. ... Edwards, H. E. (2018). The effectiveness of hyperbaric oxygen therapy forhealing 
chronic venous leg ulcers: A randomized, double-blind, placebo-controlled trial. Wound Repair Rege, 26(4), 324-331. doi: 10.1111/wrr.12657

[29] Thomas, B., Kurien, J. S., Jose, T., Ulahannan, S. E., \& Varghese, S. A. (2017). Topical timolol promotes healing of chronic leg ulcer. J. Vasc. Surg. Venous Lymphat. Disord., 5(6), 844850. doi: 10.1016/j.jvsv.2017.04.019

[30] Weller, CD, Richards, C, Turnour, L, Patey, AM., Russell, G. \& Team, V. (2020). Barriers and enablers to the use of venous leg ulcers clinical practice guidelines in Australian primary care: A qualitative study using the theoretical domains framework. Int. J. Nurs. Stud. 103. doi: 10.1016/ j.jinurstu.2019.103503

[31] Westby, M. J., Norman, G., Dumville, J. C., Stubbs, N., Cullum, N. (2016). Protease-modulating matrix treatments forhealing venous leg ulcers. Cochrane Databas. Syst. Rev., 15, 12(12), CD011918. doi: 10.1002/14651858

\section{МОРФОМЕТРИЧНА ОЦІНКА ОСОБЛИВОСТЕЙ РЕМОДЕЛЮВАННЯ ВЕНОЗНОГО РУСЛА КІНЦІВОК ПРИ ЕКСПЕРИМЕНТАЛЬНІЙ ТРОФІЧНІЙ ВИРАЗЦІ ТА ІІІ КОРЕКЦІї}

Суходоля А.І., Гнатюк М.С., Креньов К.Ю., Коломієць О.В.

Прогресуючий перебіг захворювань вен нижніх кінцівок призводить до розвитку ускладнень у понад $80 \%$ хворих на посттромботичну хворобу. Мета роботи: вивчити морфометричні особливості ремоделювання венозного русла кінцівок при експериментальній трофрічній виразці та їі корекції. Комплексом морфологічних методів досліджені вени задніх кінцівок 18 статевозрілих свиней-самців в'єтнамської породи, які були розділені на три групи: 1 група нараховувала 6 інтактних практично здорових тварин, 2 групу становили 6 свиней зі змодельованою трофічною виразкою, 3 група - 6 тварин із виразкою, корегованою лідокаїном. Вимірювали площу трофрічної виразки. Забирали трофрічну виразку разом з оточуючими тканинами, з яких виготовляли гістологічні мікропрепарати, де визначали діаметри закапілярних венул, венул, зовнішній та внутрішній діаметри венозних судин, висоту ендотеліоцитів, діаметр їх ядер, ядерно-цитоплазматичні відношення у цих клітинах, відносний об'єм пошкоджених ендотеліоцитів. Проводили кореляційний аналіз між площею виразки та морфометричними параметрами. Кількісні величини обробляли статистично. Встановлені сильні позитивні кореляційні взаємозв'язки між ядерно-цитоплазматичними відношеннями в ендотеліоцитах, відносним об'ємом пошкоджених ендотеліоцитів та площею виразкового дефекту ( $r=+0,84 \pm 0,03) ;$ при корекції виразки лідокаїном вони дещо слабшали. Виявлено, що корекція трофрічної виразки лідокаїном призводила до зменшення їі площі на 25,8\%. Встановлено, що експериментальна трофрічна виразка призводить до вираженого ремоделювання венозного русла нижніх кінцівок, яке характеризується значним розширенням венозних судин, венозним повнокров'ям, що ускладнюється гіпоксією, атрофрічними, дистрофічними, некробіотичними, інфрільтративними та склеротичними процесами. Застосування лідокаїну при експериментальній трофічній виразці покращує адаптаційно-компенсаторні та регенераторні процеси змодельованої патології, зменшує відносний об'єм пошкоджених ендотеліоцитів у венозних судинах нижньої кінцівки на 18,8\% (p<0,001).

Ключові слова: трофрічна виразка, вени, морфометрія, лідокаїн.

\section{МОРФОМЕТРИЧЕСКАЯ ОЦЕНКА ОСОБЕННОСТЕЙ РЕМОДЕЛИРОВАНИЯ ВЕНОЗНОГО РУСЛА КОНЕЧНОСТЕЙ ПРИ ЭКСПЕРИМЕНТАЛЬНОЙ ТРОФИЧЕСКОЙ ЯЗВЕ И ЕЕ КОРРЕКЦИИ \\ Суходоля А.И., Гнатюк М.С., Креньов К.Ю., Коломиец А.В.}

Прогрессирующее течение заболеваний вен нижних конечностей приводит к развитию осложнений у более $80 \%$ больных посттромботической болезнью. Цель работы: изучить морфометрические особенности ремоделирования венозного русла конечностей при экспериментальной трофической язве и ее коррекции. Комплексом морфологических методов исследованы вены задних конечностей 18 половозрелых свиней-самцов вьетнамской породы, которые были разделены на три группы: 1 группа насчитывала 6 интактных практически здоровых животных, 2 группу составили 6 свиней со смоделированной трофической язвой, 3 группа - 6 животных с язвой, корректированной лидокаином. Измеряли площадь трофической язвы. Забирали трофическую язву вместе с окружающими тканями, из которых изготавливали гистологические микропрепараты, где определяли диаметры закапилярных венул, венул, внешний и внутренний диаметры венозных сосудов, высоту эндотелиоцитов, диаметр их ядер, ядерно-цитоплазматические отношения в этих клетках, относительный объем поврежденных эндотелиоцитов. Проводили корреляционный анализ между площадью язвы и морфометрическими параметрами. Количественные величины обрабатывали статистически. Установлены сильные положительные корреляционные взаимосвязи между ядерно-цитоплазматическими отношениями в эндотелиоцитах, относительным объемом поврежденных эндотелиоцитов и площадью язвенного дефекта $(r=+0,84 \pm 0,03) ;$ при коррекции язвы лидокаином они незначительно ослабевали. Выявлено, что коррекция трофической язвы лидокаином приводила к уменьшению ее площади на 25,8\%. Установлено, что экспериментальная трофрическая язва приводит к выраженному ремоделированию венозного русла нижних конечностей, которое характеризуется значительным расширением венозных сосудов, венозным полнокровием, что осложняется гипоксией, атроффическими, дистрофическими, некробиотическими, инфрильтративными и склеротическими процессами. Применение лидокаина при экспериментальной трофической язве улучшает адаптационнокомпенсаторные и регенераторные процессы смоделированной патологии, уменьшает относительный объем поврежденных эндотелиоцитов в венозных сосудах нижней конечности на $18,8 \%(p<0,001)$.

Ключевые слова: трофическая язва, вены, морфометрия, лидокаин. 